\title{
Exposure to Covid-19: Assessing the Knowledge, Attitudes, and Practices of Anaesthetists in the Prevention of COVID-19 Spread in Ghana-A Multicenter Cross-Sectional Survey
}

Sylvanus Kampo ${ }^{*}$, Thomas Winsum Anabah ${ }^{2}$, Alexis DB Buunaaim ${ }^{3}$, Eugene Dogkotenge Kuugbee ${ }^{4}$, Jacob Mbuer Wumbei ${ }^{5}$, James Mwinsagra ${ }^{6}$, Shiraj Mohammed ${ }^{7}$ and Thomas Bavo Azongo ${ }^{8}$

${ }^{1}$ Department of Anaesthesia and Critical Care, School of Medicine, University of Health and Allied Sciences, Ghana

${ }^{2}$ Anaesthesia Unit, Habana Medical Service, Ghana

${ }^{3}$ Department of Surgery, School of Medicine and Health Sciences, University for Development Studies, Ghana

${ }^{4}$ Department of Clinical Microbiology, School of Medicine and Health Science, University for Development Studies, Ghana

${ }^{5}$ Department of Anaesthesia, Greater Accra Regional Hospital, Ghana

${ }^{6}$ Department of Anaesthesia, Komfo Anokye Teaching Hospital, Ghana

${ }^{7}$ Department of Anaesthesia, Tamale Teaching Hospital, Ghana

${ }^{8}$ Department of Public Health, School of Allied Health Sciences, University for Development Studies, Ghana

*Corresponding author: Sylvanus Kampo, Department of Anaesthesia and Critical

Care, School of Medicine, University of Health and Allied Sciences, Ghana.
Received Date: August 17, 2020

Published Date: September 25, 2020

\begin{abstract}
The number of health workers infected with COVID-19 is increasing exponentially. Recent reports indicate that about 787 frontline health workers died of COVID-19 in the United States of America. In Ghana, not less than 779 health workers especially doctors, certified registered Anaesthetists and nurses have been infected with COVID-19, with nine death. Aerosol and fomite transmission of SARS-CoV-2 to individuals is plausible. Anaesthesia professionals who are in close contact as they help patients breathe through airway equipment are at maximum risk of exposure to COVID-19. This study aimed to assess the knowledge, attitudes, and practices of Anaesthetists towards the prevention of the spread of the COVID-19 infection. Certified Registered Anaesthetists were required to complete a self-administered structured questionnaire. A total of 356 respondents were recruited in this study. The data showed that $73.3 \%$ of the respondents recruited for this study were males and $26.7 \%$ of them were females. The mean age of the respondents was $37.1 \pm 5.3$ years old. We realized that $4.8 \%$ of them always had access to appropriate personal protective equipment, whereas $95.2 \%$ of them had no access during work. The data also showed that $34.0 \%$ of them always had access to a face mask and hand sanitizers, while $66.0 \%$ of them had no access to a face mask and hand sanitizers during work. There is, the need for regular inservice training of Certified Registered Anaesthetists and other health workers on the right attitude and practices to prevent the spread of the virus among health workers. Policymakers should ensure the regular supply of basic PPE at the various hospitals.
\end{abstract}

Keywords: Anaesthetists; Knowledge; Attitudes; Practices; Prevention; SARS-CoV-2 infection; Healthcare providers

Abbreviations: SARS-CoV-2 - Severe acute respiratory syndrome coronavirus 2; COVID-19 -Coronavirus disease 2019; CRA - Certified Registered Anaesthetists; PAPR - powered air-purifying respirators; PPE - Personal Protective Equipment; CDC - Centre for Disease Control 


\section{Background}

Severe acute respiratory syndrome coronavirus 2 (SARS-CoV-2) cause the novel Coronavirus disease 2019 (COVID-19) which was first discovered amidst an outbreak of respiratory diseases in Wuhan City, China in 2019 [1]. Current reports indicate that more than 200 countries have stated laboratory-confirmed cases of COVID-19. Over 6 million individuals have been confirmed with COVID-19 and more than 293,000 related deaths worldwide [2]. Evidence shows that Ghana is one of the most affected Countries by COVID-19 in sub-Sahara Africa. As of July 9, 2020, Ghana has recorded over 24,518 confirmed cases, out of which 4,192 were active cases and 139 related deaths [3]. The outbreak of COVID-19 in Ghana has been a major health crisis affecting healthcare systems, professionals, and the population at large. The World Health Organization in March 2020 declared COVID-19 as a global health pandemic [4].

Transmission of SARS-CoV-2 is by respiratory droplets from sneezing or coughing [5]. The incubation period for newly infected individuals was found to be 5.2 days, with a range of 4.1-7 days. The period from infection to the appearance of symptoms is reported to be 12.5 days. It is reported that asymptomatic patients of COVID-19 can still transmit the infection to others. Some studies have reported that every COVID-19 patient tends to infect an average of 2.2 others [6]. In the United States, the Centre for Disease Control and Prevention (CDC) has detailed that more cases of COVID-19 are expected to be diagnosed soon worldwide. There is an anticipated SARS-CoV-2 community spread and most of the population may be exposed to the virus in the coming months, leading to a CDC recommendation against gatherings of 10 persons or more [7].

Individuals at high risk of SARS-CoV-2 infection include persons in areas with ongoing local transmission, close contacts of infected persons, travelers returning from places where local spread has been reported, and healthcare workers caring for patients with COVID-19 [8]. Data show that aerosol and fomite transmission of SARS-CoV-2 to individuals is plausible. The virus can stay viable and infectious in aerosols and on surfaces for 72 hours or more [9]. Amid COVID-19 pandemic, the American Society of Anaesthesiologists, American Academy of Anaesthesiologists Assistants, American Association of Nurse Anaesthetists, and the Anaesthesia Patient Safety Foundation issued a joint statement which indicates that anaesthesia professionals who are in close contact as they help patients breathe through airway equipment are at high risk of exposure to COVID-19 [10]. This study, therefore, aimed to assess the knowledge, attitudes, and practices of anaesthetists working in a less-resourced country amid the COVID-19 pandemic towards the prevention of the spread of SARS-CoV-2 infection.

\section{Methods}

\section{Ethical Statement}

This prospective cross-sectional survey was carried out at some major hospitals in Ghana from April to July 2020. The Ethical
Review Committee of the Tamale Teaching Hospital approved the study protocol. Written informed consent was obtained from individual respondents after providing them with adequate explanations regarding the aims of the study.

\section{Subjects}

A total of three hundred and fifty-six (356) Certified Registered Anaesthetists (CRA) were recruited into the study. These were anaesthetists who administered anaesthetics to patients in Ghana during the study period. The inclusion criteria were as follows: All CRAs who practised anaesthesia in Ghana and have consented to take part in this study. The exclusion criteria were as follows: eligible CRAs who declined to participate in this study. All eligible CRAs who consented to take part in this study were required to complete a self-administered structured questionnaire which was developed for this study electronically.

\section{Measurements}

The primary outcomes measured were knowledge, attitudes, and practices among anaesthetists in Ghana towards the prevention of the spread of SARS-CoV-2 infection in hospitals in Ghana. The secondary outcomes measured were demographic characteristics such as age, sex, educational background, and years of practice.

\section{Statistical analysis}

The sample size for this study was calculated using the formula [11].

Necessary Sample Size $=(\text { Z-score })^{2} * \operatorname{StdDev}^{*}(1-$ StdDev $) /$ (margin of error) ${ }_{2}$

95\% confidence interval (Z-score $=1.96)$, Standard Deviation $($ StdDev $=0.5)$ and margin of error $= \pm 5$ or $6 \%$. Therefore, our sample size adjustment was between 267 and 384 respondents.

All statistical analyses were carried out using the Statistical Package for Social Sciences Software (SPSS) version 20.01 (IBM Corporation, Armonk, NY, USA). The results were presented as means, frequencies and tables. The confidence interval was $95 \%$ and considered statistically significant at $\mathrm{P}<0.05$. One-way ANOVA and multiple comparisons by Tukey's test were used to make statistical comparisons between three or more groups. The student's t-test was used for statistical comparisons between two groups.

\section{Results}

\section{Demographic characteristics of respondents}

A total of 358 respondents were recruited in this study. Data for two were incomplete and were excluded from the data analysis. Therefore, data for 356 respondents were included in the analysis.

The data showed that 261 (73.3\%) of the respondents recruited for this study were males and 95 (26.7\%) of them were females working in various hospitals in Ghana (Table 1). We also realized that $15(4.2 \%)$ of the respondents were 30 or less years old, 154 
(43.3\%) of them were within the age range of 31-35 years old, 159 (44.4\%) of them were between 36-45 years old, whereas 29 (8.1 $\%)$ of them were 46 and above years old (Table 1). The mean age of the respondents was $37.1 \pm 5.3$ years old. We assessed respondents level of education and realized that $224(62.9 \%)$ of them had a bachelor degree in anaesthesia, 110 (30.9 \%) had an advance diploma in anaesthesia, $2(0.6 \%)$ had the Fellowship training in anaesthesia, whereas 20 (5.6\%) had an additional qualification in different health-related programs at the Master degree level (Table 1). The data also showed that 257 (72.2\%) of the respondents were working in government hospitals, 88 (24.7\%) were working in Christian Health Associations of Ghana (CHAG) hospitals, while 11 $(3.1 \%)$ were working in private hospitals (Table 1). The individual respondents' years of practice were assessed. The data showed that $165(46.3 \%)$ of them had 5 or less years of anaesthesia practice, 121 (34.0\%) of them had 6-10 years of anaesthesia practice, whereas $70(19.7 \%)$ of them had 11 or more years of practice (Table 1). To determine the workload on individual anaesthetists at the various hospitals across the country during the COVID-9 pandemic, we assessed to know the number of anaesthetists working in each hospital. The data showed that 287 (80.7\%) of the respondents indicated that they had 10 or less anaesthetists working in their hospitals, 32 (9.0 \%) had between 11-20 anaesthetists working in their hospitals, while 37.0 (10.4\%) had 21 and above anaesthetists in their hospital (Table 1).

\section{Exposure to SARS-CoV-2 infection among clinical anaesthesia providers in Ghana}

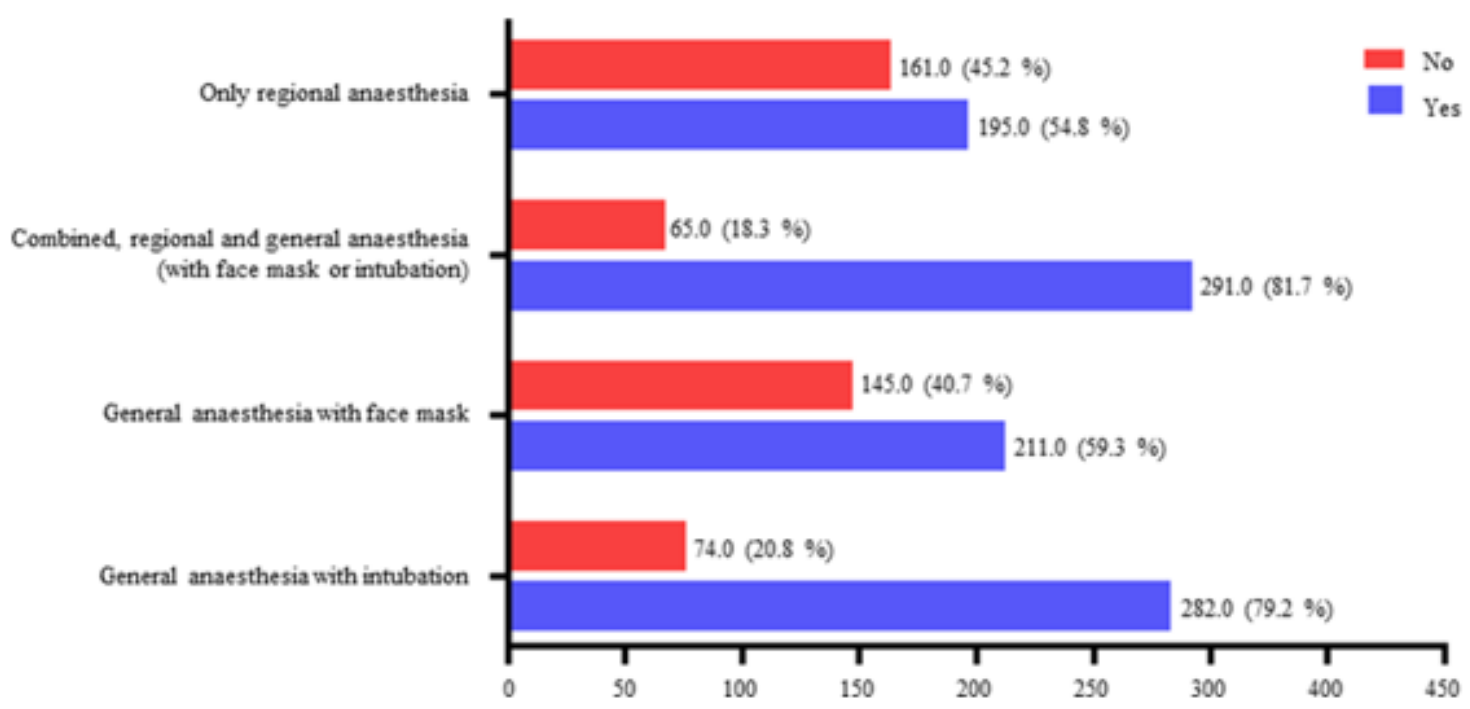

Figure 1: Anaesthesia techniques commonly adopted for patients by the anaesthetists amid COVID-19 in Ghana.

Table 1:

\begin{tabular}{|c|c|c|c|}
\hline \multicolumn{2}{|c|}{ Measurements } & Frequency & Percentage (\%) \\
\hline \multirow{5}{*}{ Age (Years) } & 30 or less & 15 & 4.2 \\
\hline & $31-35$ & 154 & 43.3 \\
\hline & $36-45$ & 158 & 44.4 \\
\hline & 46 and above & 29 & 8.1 \\
\hline & Total & 356 & 100 \\
\hline \multirow{3}{*}{ Sex } & Female & 95 & 26.7 \\
\hline & Male & 261 & 73.3 \\
\hline & Total & 356 & 100 \\
\hline \multirow{5}{*}{ Educational level } & Advance Diploma & 110 & 30.9 \\
\hline & Degree & 224 & 62.9 \\
\hline & Fellowship & 2 & 0.6 \\
\hline & Master & 20 & 5.6 \\
\hline & Total & 356 & 100 \\
\hline
\end{tabular}




\begin{tabular}{|c|c|c|c|}
\hline \multirow{4}{*}{ Years of practice (Years) } & 5 or less & 165 & 46.3 \\
\hline & $6-10$ & 121 & 34 \\
\hline & 11 and above & 70 & 19.7 \\
\hline & Total & 356 & 100 \\
\hline \multirow{4}{*}{ Employer } & CHAG & 88 & 24.7 \\
\hline & Government Institution & 257 & 72.2 \\
\hline & Private Organization & 11 & 3.1 \\
\hline & Total & 356 & 100 \\
\hline \multirow{5}{*}{ Hospital bed capacity } & 100 or less & 162 & 45.5 \\
\hline & $101-300$ & 135 & 37.9 \\
\hline & $301-600$ & 33 & 9.3 \\
\hline & 601 and above & 26 & 7.3 \\
\hline & Total & 356 & 100 \\
\hline \multirow{4}{*}{ How many anaesthetists are there in your hospital? } & 10 or less & 287 & 80.6 \\
\hline & $11-20$ & 32 & 9 \\
\hline & 21 and above & 37 & 10.4 \\
\hline & Total & 356 & 100 \\
\hline
\end{tabular}

Table 2: Risk of exposure to SARS-CoV-2 infection among clinical anaesthesia providers in Ghana.

\begin{tabular}{|c|c|c|c|c|c|c|c|c|}
\hline \multirow{2}{*}{ Measurements } & \multicolumn{2}{|r|}{ Yes } & \multicolumn{2}{|r|}{ No } & \multicolumn{2}{|c|}{ I don't Know } & \multicolumn{2}{|c|}{ Total } \\
\hline & Frequency & Percentage (\%) & Frequency & Percentage (\%) & Frequency & Percentage (\%) & Frequency & Percentage (\%) \\
\hline $\begin{array}{l}\text { Have you given } \\
\text { anaesthesia to } \\
\text { any suspect- } \\
\text { ed covid-19 } \\
\text { patient? }\end{array}$ & 55 & 15.4 & 215 & 60.4 & 86 & 24.2 & 356 & 100 \\
\hline $\begin{array}{l}\text { Have you had } \\
\text { any training on } \\
\text { taking care of } \\
\text { patients during } \\
\text { this covid-19 } \\
\text { pandemic? }\end{array}$ & 80 & 22.5 & 276 & 77.5 & 0 & 0 & 356 & 100 \\
\hline $\begin{array}{l}\text { During this } \\
\text { COVID-19 pan- } \\
\text { demic, have you } \\
\text { ever been called } \\
\text { to help manage } \\
\text { a patient in } \\
\text { another unit } \\
\text { within your } \\
\text { hospital? }\end{array}$ & 250 & 70.2 & 106 & 29.8 & 0 & 0 & 356 & 100 \\
\hline $\begin{array}{l}\text { During this pan- } \\
\text { demic, have you } \\
\text { ever been sus- } \\
\text { pected of having } \\
\text { COVID-19? }\end{array}$ & 43 & 12.1 & 313 & 87.9 & 0 & 0 & 356 & 100 \\
\hline $\begin{array}{l}\text { Have you ever } \\
\text { been tested for } \\
\text { COVID-19? }\end{array}$ & 52 & 14.6 & 304 & 85.4 & 0 & 0 & 356 & 100 \\
\hline $\begin{array}{l}\text { Do you recom- } \\
\text { mend testing } \\
\text { all patient for } \\
\text { COVID } 19 \text { before } \\
\text { administering } \\
\text { anaesthesia? }\end{array}$ & 286 & 80.3 & 60 & 16.9 & 10 & 2.8 & 356 & 100 \\
\hline
\end{tabular}




\begin{tabular}{|c|c|c|c|c|c|c|c|c|}
\hline $\begin{array}{l}\text { Are you a front } \\
\text { liner in the } \\
\text { control and } \\
\text { management } \\
\text { of COVID-19 } \\
\text { patients? }\end{array}$ & 133 & 37.4 & 147 & 41.3 & 76 & 21.3 & 356 & 100 \\
\hline $\begin{array}{c}\text { Amid COVID-19, } \\
\text { do your hospital } \\
\text { always provide } \\
\text { enough PPEs to } \\
\text { protect yourself } \\
\text { during anaes- } \\
\text { thesia practice? }\end{array}$ & 17 & 4.8 & 339 & 95.2 & 0 & 0 & 356 & 100 \\
\hline $\begin{array}{l}\text { Is face mask and } \\
\text { hand sanitizers } \\
\text { always available } \\
\text { at your hospital } \\
\text { during anaes- } \\
\text { thesia practice } \\
\text { amid COVID-19? }\end{array}$ & 121 & 34 & 235 & 66 & 0 & 0 & 356 & 100 \\
\hline $\begin{array}{c}\text { Beside your } \\
\text { hospital, do } \\
\text { you practice } \\
\text { anaesthesia in } \\
\text { another hospital } \\
\text { amid COVID-19? }\end{array}$ & 105 & 29.5 & 251 & 70.5 & 0 & 0 & 356 & 100 \\
\hline
\end{tabular}

We assessed to know the possible exposure to COVID-19 infection during anaesthesia practice among the clinical anaesthesia providers in Ghana. First, we asked the anaesthesia providers to know if they have ever given anaesthesia to any suspected covid-19 patient during the pandemic. The data showed that 55 (15.4\%) of the respondents answered yes, 215 (60.4\%) of them answered no, while 86 (24.2\%) of them said they did not know (Table 2). We asked to know if the anaesthesia providers have received any form of training on how to take care of patients during this covid-19 pandemic. The data revealed that $80(22.5 \%)$ of the respondents said yes, whereas 276 (77.5 \%) of them said no (Table 2). We also asked the respondents to know if they have ever been called to help manage a patient in another unit within their hospitals. The data showed that 250 (70.2\%) of them said yes, while 206 (29.8\%) of them said no (Table 2). When asked if, during this pandemic, any of the respondents have ever been suspected of having COVID-19, the findings indicated that 43(12.1\%) of them answered yes, while $313(87.9 \%)$ of them said no (Table 2). We also asked the anaesthesia provider if they have ever been tested for COVID-19 during the pandemic. We realized that 52 (14.6\%) of them answered yes, whereas 304 (85.4\%) of them answered no (Table 2). The data also showed that 286 (80.3\%) of the respondents said yes, $60(16.9 \%)$ of them said no, while 10 (2.8\%) of them said they do not know when we asked them if they will recommend that all patients should be tested for COVID-19 before anaesthesia is administered (Table 2). The anaesthetists were asked if they were front liners in the control and management of COVID-19 patients in their hospitals. The data showed that 133 (37.4\%) of them said yes, $147(41.3 \%)$ of them said no, while 76 (21.3\%) of them said they did not know (Table 2). We asked the respondents to know if, amid the COVID-19 pandemic, their hospitals always provide them with enough appropriate personal protective equipment (PPE) to protect themselves during anaesthesia practice. We realized that 17 (4.8\%) of them said yes, whereas 339 (95.2\%) of them said no (Table 2). The respondents were also asked if face mask and hand sanitizers were always made available in their hospitals amid COVID-19 pandemic. The results showed that 121 (34.0\%) of them answered yes, while 235 (66.0\%) of them answered no (Table 2). We asked the anaesthetists to know if besides the hospitals they practice anaesthesia, they also work in another hospital amid COVID-19. The data showed that 105 (29.5\%) of the respondent answered yes, while 251 (70.5 \%) of them said no. Anaesthesia techniques commonly adopted for patients by the anaesthetists amid COVID-19 in Ghana was also assessed. The data showed that $282(79.2 \%)$ of the certified registered anaesthetists in Ghana used general anaesthesia with intubation, 211 (59.3\%) of them used general anaesthesia with facemask, 291 (81.7\%) of them used combined general and regional anaesthesia with facemask or intubation, whereas 195 (54.8\%) used only regional anaesthesia for patients (Figure 1).

\section{Knowledge of COVID-19 disease among clinical anaesthesia providers in Ghana}

We assessed the respondent's knowledge of COVID-19. The anaesthetists were asked if someone with COVID-19 cannot infect others with the virus if the fever doesn't persist. The data showed that 2(0.6\%) of them answered yes, while 354 (99.4\%) answered no (Table 3). We asked to know whether the epidemiologic characteristic of COVID-19 virus arises from high viral loads in the upper respiratory tract. The results showed that 313 (87.9\%) of 
the respondents said yes, 27 (7.6\%) of them said no, whereas 16 (4.5\%) of them said they did not know (Table 3). We asked the anaesthetists to know if COVID-19 virus can be transmitted through aerosols. The data showed that 330 (92.7) of the respondents answered yes, 12 (3.4\%) of them answered no, whereas 14 (3.9 $\%)$ of them said they did not know (Table 3). When asked if the anaesthetist is at high risk of getting COVID-19 through clinical practice. The findings showed that 355 (99.7\%) of the respondents said yes, while $1(0.3 \%$ ) said he/she did not know (Table 3$)$. They were also asked if wearing a face mask will help in preventing the spreads of COVID-19 during anaesthesia practice. The data showed that 339 (95.2\%) of the anaesthetists said yes, 14(3.9\%) of them said no, while $3(0.8 \%)$ of them said they did not know (Table 3). Without specifying the type of face mask, we asked the anaesthetists, amid COVID-19, was it ok for one to store and reuse his/her face mask later once he/she was not infected with COVID-19 virus. The data showed that 47 (13.2\%) of the respondents said yes, while 299 (84 \%) of them said no (Table 3). We also asked to know if wearing gloves always during anaesthesia practice will help in preventing the spread of COVID-19. The data showed that 323 $(90.7 \%)$ of the respondents answered yes, while 33 (9.3\%) of them answered no (Table 3). Also, we asked the anaesthetists to know if washing hands frequently for at least 20 seconds or disinfecting with alcohol-based sanitizers during anaesthesia practice will help in preventing the spread of COVID-19. We realized that 350 $(98.3 \%)$ of the respondents answered yes, whereas $6(1.7 \%)$ of them answered no (Table 3). The anaesthetists were again asked if avoiding crowded places during anaesthesia practice will help in preventing the spread of COVID-19. The result showed that 348 (97.8) of the respondents said yes, while 8 (2.2\%) of them said no (Table 3). We found out from the anaesthetists whether or not greeting through handshaking will help in preventing the spread of COVID-19 during or after anaesthesia practice. The findings indicated that 348 (97.8) of the respondents said yes, whereas $8(2.2 \%)$ of them said no (Table 3$)$. We asked to find out if there were some vaccines on the market to prevent COVID-19. The data showed that $2(0.6 \%)$ of the anaesthetists said yes, $334(93.8 \%)$ of them said no, while 20 (5.6 \%) of them said they did not know (Table 3).

We further investigated to determine the respondent's knowledge of clinical symptoms of COVID-19 and the group of people that are at risk of getting infected with COVID-19. The data showed that 349 (98.0\%) of the respondents said yes, fever was one of the early clinical symptoms, while 7 (2.0\%) of them said fever wasn't a clinical symptom of COVID-19 (Table 4). We asked to know if dry cough was among the early clinical symptoms of COVID-19. The data showed that 348 (97.0\%) of the anaesthetists answered yes, 7 (2.0\%) of them answered no, whereas 1 (0.3\%) of them said he/she did not know (Table 4). It was observed that 289 (81.2\%) of the respondents answered yes, 48(13.5\%) answered no, while 19 (5.3) of them said they did not know when they were asked if fatigue was one of the clinical symptoms of COVID-19 (Table 4). We asked to know if sore throat was one of the clinical symptoms of COVID-19. The data showed that 321 (90.1\%) of the respondents said yes, 24.9 (6.7\%) of them said no, and 11 (3.1\%) of them said they did not know (Table 4). The anaesthetists were again asked if difficulty in breathing was a clinical symptom of severe COVID-19. The findings indicated that 355 (99.7\%) of the respondents said yes, while 1 ( 0.3 ) of them said no (Table 4). Respondents were also asked if myalgia and diarrhoea were some of the clinical symptoms of COVID-19. The data showed that 208 (58.4\%), 143 (40.2\%) of them said yes, 90 (25.3\%), 116 (32.6\%) of them said no, whereas $58(16.2 \%), 97$ (27.2\%) of them said they did not know respectively (Table 4). We also assessed to know the group of people that are at risk of getting infected with COVID-19. The respondents were asked if everybody was at risk of getting infected with COVID-19. The data showed that 346 (97.2\%) of the respondents said yes, $7(2.0 \%)$ of them said no, while $3(0.8 \%)$ of them said they did not know (Figure 2). The anaesthetists were also asked if people with chronic illness are at risk of getting infected with COVID-19. The results showed that 336 (94.4\%) of the respondents said yes, 19 (5.3\%) of them said no, while $1(0.3 \%)$ of them said they do not know. Also, the respondents were asked if people 50 years and above were at risk of getting infected with COVID-19. The data showed that 337 (94.7\%) of the respondents answered yes, 17 (4.8 $\%)$ of them answered no, and $2(0.6 \%)$ of them said they did not know (Figure 2).

\section{Attitude and practices of clinical anaesthesia providers in the prevention of the spread of SARS-CoV-2 infection in Ghana}

To determine if the clinical anaesthesia providers in Ghana are at risk of COVID-19 infection, we assessed their attitudes and practices of anaesthesia amid COVID-19. We asked respondents to know if they still carry out a pre-anaesthetic assessment before a patient is brought into the theatre amid the COVID-19 pandemic. The findings showed that $260(73.0 \%)$ of them always did the pre-anaesthetic assessment, 89 (25.0\%) of them sometimes did the pre-anaesthetic assessment, and 7 (2.0\%) of them never did the pre-assessment amid COVID-19 (Table 5). We also enquired from the anaesthetists to know if, during this covid-19 pandemic, they always intubate or extubate patients in the presence of other theatre staff. We realized that 148 (41.6.0) of them always did intubate or extubate patients in the presence of other theatre staff without the appropriate precautionary measures, 172 (48.3.0) of them sometimes did intubate or extubate a patient in the presence of other theatre staff without the appropriate precautionary measures, whereas 36 (10.1\%) of them amid COVID-19, never intubated or extubated a patient in the presence of other theatre staff (Table 5). We also asked the respondents to know if face masks and hand sanitizers were always made available for their use in their hospitals amid COVID-19 pandemic. The data showed that 
121 (34.0) of them said that face masks and hand sanitizers were always made available for their use in the hospital, 229 (64.2\%) of them said that face masks and hand sanitizers were sometimes made available for their use, while 6 (1.7) of them said that amid COVID-19 pandemic, face masks and hand sanitizers have never been made available for their use in the hospitals (Table 5). The data also showed that 320 (89.9), 24 (6.7), and 12 (3.4) of the anaesthetists always, sometimes, or never wear a face mask when intubating or extubating a patient during anaesthesia respectively (Table 5). We also observed that 40 (11.2), 12 (3.4\%) and 304 (85.4) of the anaesthetists indicated that they were always, sometimes, or never (respectively) opposed to wearing a face mask when giving anaesthesia (Table 5). The anaesthetists were asked to know if they used soap and running water to wash their hands after intubating or extubating a patient amid COVID-19. The findings showed that 289 (81.2 \%) of the respondents always washed their hands with soap and running water after intubating or extubating a patient, $63(17.7 \%)$ of them sometimes washed their hands with soap and running water after intubating or extubating a patient, while $4(1.1 \%)$ of them never washed their hands with soap and running water after intubating or extubating a patient (Table 5). We asked the respondents to know if, amid covid-19 pandemic, they always used disinfectants, disposable wipes, or sanitizers on their hands before and after attending to a patient. The data showed that 233 (65.4) of the anaesthetists always used disinfectants, disposable wipes or sanitizers on their hands before and after attending to a patient, 116 (32.6\%) of them sometimes used the disinfectants, disposable wipes or sanitizers on their hands before and after attending to a patient, while 7 (2.0\%) of them never used the disinfectants, disposable wipes or sanitizers on their hands before and after attending to a patient (Table 5). We inquired to know if, the anaesthetists always washed their hands or use hand sanitizers after touching personal items of a patient. The evidence showed that $221(62.1 \%)$ of them always washed their hands or used the hand sanitizers after touching patient's items, 134 (37.6) of them sometimes washed their hands or used the hand sanitizers after touching personal items of a patient, whereas $1(0.3 \%)$ of them never washed hands or used the hand sanitizers after touching personal items of a patient (Table 5). The respondents were asked if they always wash their hands or use sanitizers after shaking hands with patients. The results showed that 268 (75.3) of them always wash their hands or use sanitizers after shaking hands with patients, $80.0(22.5 \%)$ of them sometimes wash their hands or use sanitizers after shaking hands with patients, while 8 (2.2\%) of them never wash their hands or use sanitizers after shaking hands with patients(Table 5). We further inquired from the anaesthetists to know if they always wash their hands or use the hand sanitizers after touching the theatre doorknobs. The data showed that 135 (37.9) of them washed their hands or used sanitizers after touching the theatre doorknobs, 209 (58.7\%) of them sometimes wash their hands or use the hand sanitizers after touching the theatre doorknobs, and 12 (3.4\%) of them never wash their hands or use the hand sanitizers after touching the theatre doorknobs (Table 5). We also asked the respondents to know if, amid COVID-19 they always refrained from being close to patients who cough, sneeze, or have a cold. The findings indicated that 197 (55.3\%) of the anaesthetists always refrained from being close to patients who cough, sneeze or have a cold, 136 (38.2\%) of them sometimes refrained from being close to patients who cough, sneeze or have a cold, while 23 (6.5\%) of them never refrained from being close to patients who cough, sneeze or had a cold (Table 5). Finally, we asked the anaesthetists to know if they always refrained from touching their noses or faces during work. The data showed that 101 (28.4) of the respondents always refrained from touching their noses or faces during work, 253 (71.1\%) of them sometimes refrained from touching their noses or faces, while $2(0.6 \%)$ of them never refrained from touching their noses or faces during work (Table 5).

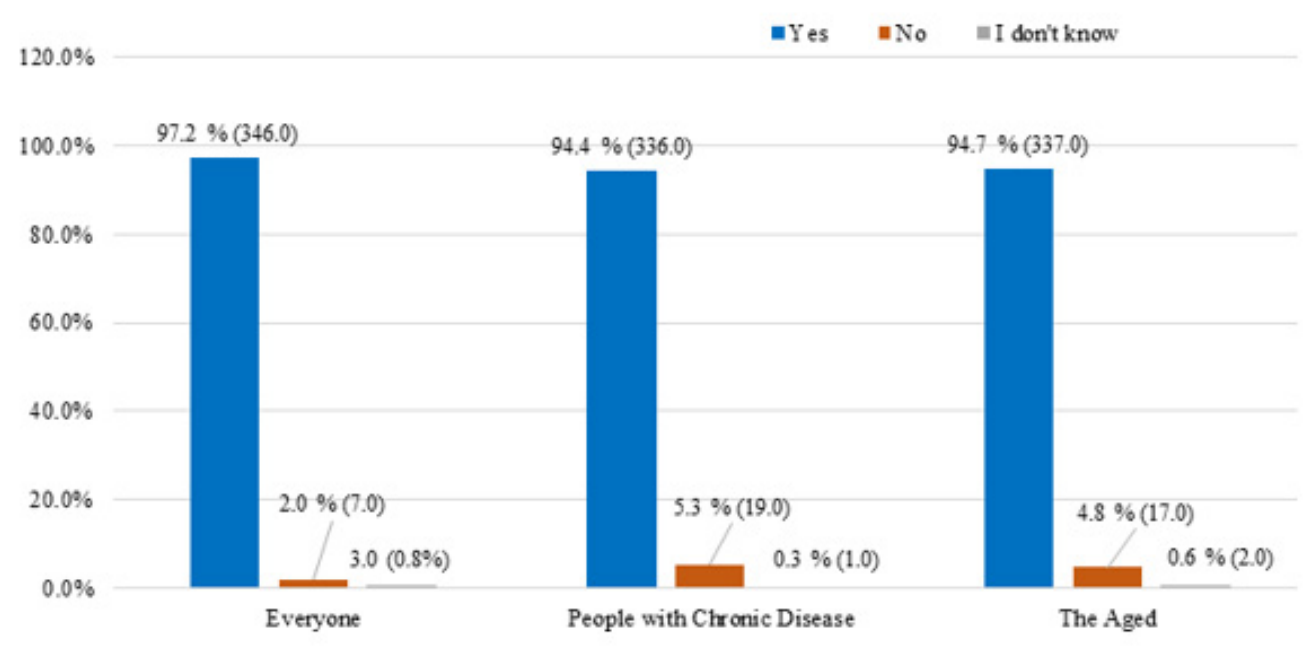

Figure 2: Group of people at risk of getting infected with COVID-19 Virus in Ghana. 
Table 3: Knowledge of COVID-19 disease among clinical anaesthesia providers in Ghana.

\begin{tabular}{|c|c|c|c|c|c|c|c|c|}
\hline \multirow[b]{2}{*}{ Measurements } & \multicolumn{2}{|r|}{ Yes } & \multicolumn{2}{|c|}{ No } & \multicolumn{2}{|c|}{ I don't Know } & \multicolumn{2}{|c|}{ Total } \\
\hline & $\begin{array}{l}\text { Frequen- } \\
\text { cy }\end{array}$ & Percentage (\%) & Frequency & $\begin{array}{c}\text { Percentage } \\
(\%)\end{array}$ & Frequency & Percentage (\%) & Frequency & $\begin{array}{l}\text { Percent- } \\
\text { age (\%) }\end{array}$ \\
\hline $\begin{array}{l}\text { Someone infected with } \\
\text { COVID-19 cannot infect } \\
\text { others with the virus if } \\
\text { fever doesn't persist }\end{array}$ & 2 & 0.6 & 354 & 99.4 & 0 & 0 & 356 & 100 \\
\hline $\begin{array}{l}\text { The epidemiologic char- } \\
\text { acteristic of COVID-19 } \\
\text { virus arises from high } \\
\text { viral loads in the upper } \\
\text { respiratory tract. }\end{array}$ & 313 & 87.9 & 27 & 7.6 & 16 & 4.5 & 356 & 100 \\
\hline $\begin{array}{c}\text { COVID-19 virus can be } \\
\text { transmitted through } \\
\text { aerosols }\end{array}$ & 330 & 92.7 & 12 & 3.4 & 14 & 3.9 & 356 & 100 \\
\hline $\begin{array}{l}\text { The anaesthetist is at high } \\
\text { risk of getting COVID-19 } \\
\text { through clinical practice. }\end{array}$ & 355 & 99.7 & 0 & 0 & 1 & 0.3 & 356 & 100 \\
\hline $\begin{array}{l}\text { Wearing a face mask } \\
\text { during and after anaes- } \\
\text { thesia practice may help } \\
\text { in preventing COVID-19 } \\
\text { spread. }\end{array}$ & 339 & 95.2 & 14 & 3.9 & 3 & 0.8 & 356 & 100 \\
\hline $\begin{array}{l}\text { One can store and reuse } \\
\text { his/her face mask later } \\
\text { once he/she is not infect- } \\
\text { ed with COVID-19 virus. }\end{array}$ & 47 & 13.2 & 299 & 84 & 10 & 2.8 & 356 & 100 \\
\hline $\begin{array}{l}\text { Wearing gloves always } \\
\text { during anaesthesia prac- } \\
\text { tice may help in prevent- } \\
\text { ing COVID-19 spread. }\end{array}$ & 323 & 90.7 & 33 & 9.3 & 0 & 0 & 356 & 100 \\
\hline $\begin{array}{l}\text { Washing hands frequently } \\
\text { for at least } 20 \text { seconds } \\
\text { or disinfecting with } \\
\text { alcohol-based sanitizers } \\
\text { during anaesthesia prac- } \\
\text { tice may help in prevent- } \\
\text { ing COVID-19 spread. }\end{array}$ & 350 & 98.3 & 6 & 1.7 & 0 & 0 & 356 & 100 \\
\hline $\begin{array}{l}\text { Avoiding crowded places } \\
\text { during anaesthesia prac- } \\
\text { tice may help in prevent- } \\
\text { ing COVID-19 spread. }\end{array}$ & 348 & 97.8 & 8 & 2.2 & 0 & 0 & 356 & 100 \\
\hline $\begin{array}{l}\text { Not greeting through } \\
\text { handshaking during or } \\
\text { after anaesthesia practice } \\
\text { may help in preventing } \\
\text { COVID-19 spread. }\end{array}$ & 348 & 97.8 & 8 & 2.2 & 0 & 0 & 356 & 100 \\
\hline $\begin{array}{l}\text { Currently, there are } \\
\text { vaccines on the market to } \\
\text { prevent COVID-19. }\end{array}$ & 2 & 0.6 & 334 & 93.8 & 20 & 5.6 & 356 & 100 \\
\hline
\end{tabular}

Table 4: Clinical Symptoms associated with COVID-19.

\begin{tabular}{|c|c|c|c|c|c|c|c|c|}
\hline & \multicolumn{2}{|c|}{ Yes } & \multicolumn{2}{c|}{ No } & \multicolumn{2}{c|}{ I don't Know } & \multicolumn{2}{c|}{ Total } \\
\cline { 2 - 10 } & Frequency & $\begin{array}{c}\text { Percentage } \\
\text { (\%) }\end{array}$ & Frequency & $\begin{array}{c}\text { Percentage } \\
(\%)\end{array}$ & $\begin{array}{c}\text { Frequency } \\
\text { Fever }\end{array}$ & $\begin{array}{c}\text { Percentage } \\
\text { (\%) }\end{array}$ & $\begin{array}{c}\text { Frequency } \\
\text { Percentage } \\
(\%)\end{array}$ \\
\hline Dry Cough & 349 & 98 & 7 & 2 & 0 & 0 & 356 & 100 \\
\hline Fatigue & 289 & 81.2 & 48 & 13.5 & 19 & 5.3 & 356 & 100 \\
\hline Sore throat & 321 & 90.1 & 24 & 6.7 & 11 & 3.1 & 356 & 100 \\
\hline $\begin{array}{c}\text { Difficulty in } \\
\text { Breathing }\end{array}$ & 355 & 99.7 & 1 & 0.3 & 0 & 0 & 356 & 100 \\
\hline
\end{tabular}




\begin{tabular}{|c|c|c|c|c|c|c|c|c|}
\hline Myalgia & 208 & 58.4 & 90 & 25.3 & 58 & 16.2 & 356 & 100 \\
\hline Diarrhoea & 143 & 40.2 & 116 & 32.6 & 97 & 27.2 & 356 & 100 \\
\hline
\end{tabular}

Table 5: Attitudes and practices of clinical anaesthesia providers in the prevention of the spread of SARS-CoV-2 infection in Ghana.

\begin{tabular}{|c|c|c|c|c|c|c|c|c|}
\hline \multirow[b]{2}{*}{ Measurements } & \multicolumn{2}{|c|}{ Always } & \multicolumn{2}{|c|}{ Sometimes } & \multicolumn{2}{|c|}{ Never } & \multicolumn{2}{|c|}{ Total } \\
\hline & $\begin{array}{c}\text { Frequen- } \\
\text { cy }\end{array}$ & $\begin{array}{l}\text { Percentage } \\
(\%)\end{array}$ & Frequency & $\begin{array}{c}\text { Percentage } \\
\text { (\%) }\end{array}$ & Frequency & $\begin{array}{c}\text { Percentage } \\
\text { (\%) }\end{array}$ & Frequency & Percentage (\%) \\
\hline $\begin{array}{l}\text { Do you always do a pre-an- } \\
\text { aesthetic assessment } \\
\text { before a patient is brought } \\
\text { into the theatre during this } \\
\text { COVID-19 pandemic? }\end{array}$ & 260 & 73 & 89 & 25 & 7 & 2 & 356 & 100 \\
\hline $\begin{array}{l}\text { During this covid-19 } \\
\text { pandemic, do you always } \\
\text { intubate or extubate in the } \\
\text { presence of other theatre } \\
\text { staff? }\end{array}$ & 148 & 41.6 & 172 & 48.3 & 36 & 10.1 & 356 & 100 \\
\hline $\begin{array}{l}\text { How available are face } \\
\text { masks and hand sanitizers } \\
\text { at your hospital? }\end{array}$ & 121 & 34 & 229 & 64.3 & 6 & 1.7 & 356 & 100 \\
\hline $\begin{array}{l}\text { Do you always wear a face } \\
\text { mask when intubating or } \\
\text { extubating a patient after } \\
\text { anaesthesia? }\end{array}$ & 320 & 89.9 & 24 & 6.7 & 12 & 3.4 & 356 & 100 \\
\hline $\begin{array}{c}\text { I am opposed to wearing } \\
\text { face Mask when giving } \\
\text { anaesthesia. }\end{array}$ & 40 & 11.2 & 12 & 3.4 & 304 & 85.4 & 356 & 100 \\
\hline $\begin{array}{l}\text { Do you always use soap } \\
\text { and running water to } \\
\text { wash your hands after } \\
\text { intubating or extubating a } \\
\text { patient? }\end{array}$ & 289 & 81.2 & 63 & 17.7 & 4 & 1.1 & 356 & 100 \\
\hline $\begin{array}{l}\text { Do you always use } \\
\text { disinfectants, disposable } \\
\text { wipes or sanitizers on your } \\
\text { hands before and after } \\
\text { attending to a patient? }\end{array}$ & 233 & 65.4 & 116 & 32.6 & 7 & 2 & 356 & 100 \\
\hline $\begin{array}{l}\text { Do you always wash your } \\
\text { hands or use hand sanitiz- } \\
\text { ers after touching personal } \\
\text { items of a patient? }\end{array}$ & 221 & 62.1 & 134 & 37.6 & 1 & 0.3 & 356 & 100 \\
\hline $\begin{array}{l}\text { Do you wash or use } \\
\text { sanitizers on your hands } \\
\text { after shaking hands with } \\
\text { patients? }\end{array}$ & 268 & 75.3 & 80 & 22.5 & 8 & 2.2 & 356 & 100 \\
\hline $\begin{array}{c}\text { Do you wash or use } \\
\text { sanitizers on your hands } \\
\text { after touching the theatre } \\
\text { doorknobs? }\end{array}$ & 135 & 37.9 & 209 & 58.7 & 12 & 3.4 & 356 & 100 \\
\hline $\begin{array}{c}\text { Do you refrain from being } \\
\text { close to patients who } \\
\text { cough, sneeze or have a } \\
\text { cold? }\end{array}$ & 197 & 55.3 & 136 & 38.2 & 23 & 6.5 & 356 & 100 \\
\hline $\begin{array}{l}\text { Do you refrain from touch- } \\
\text { ing your nose or face? }\end{array}$ & 101 & 28.4 & 253 & 71.1 & 2 & 0.6 & 356 & 100 \\
\hline
\end{tabular}

\section{Discussion}

COVID-19 patients can present with asymptomatic, minimal, or severe symptoms. A suspected case of COVID-19 may present with an acute respiratory illness such as fever, cough, or shortness of breath with no etiology that may fully explain the clinical presentation. A probable COVID-19 case is a suspected case for whom testing for COVID-19 is uncertain, whereas a confirmed case is a person, regardless of the clinical signs and symptoms has been confirmed by laboratory testing of COVID-19 infection [12]. Currently, testing for COVID-19 is not commonly or promptly available in Ghana. In the clinical care setting, identification of a person who is positive or negative to COVID-19 is not likely. 
Healthcare professionals are at high risk of exposure to COVID-19. The number of health workers infected with COVID-19 is increasing exponentially. Recent reports indicate that about 787 frontline health workers died of COVID-19 in the United States of America [13]. In Ghana, not less than 779 health workers especially doctors and nurses have been infected with COVID-19, with nine death [14]. Clinical anaesthesia providers during anaesthesia practices constantly come in contact with aerosols and stand a high risk of SARS-CoV-2 infection [10]. Airborne transmission of coronaviruses by aerosol-generating procedures such as intubation, suction and tracheostomies can occur and precautions should be taken by all clinical anaesthesia providers like wearing or using PPE like goggles, masks face shields when dealing with a patient's airway [10]. Provision of PPE by hospitals is a precautionary action to protect staffs. Conversely, the findings of this study revealed that about $95.2 \%$ of Certified Registered Anaesthetists (CRAs) practicing in Ghana have no access to PPE. Also, about $66.0 \%$ of the CRAs in Ghana have no access to a face mask at work. Despite the challenges faced by the CRAs in Ghana amid the COVID-19, majority of them still give general anaesthesia with intubation to patients and about a quarter of them administered anaesthesia to persons who were suspected having COVID-19 (Table 1) (Figure1). These emerging pieces of evidence suggest that clinical anaesthesia providers in Ghana during work are at high risk of getting infected with SARS-CoV-2 and this could be the case in most developing countries.

Hand washing, using a disinfectant solution, and avoiding contact with patients are some of the basic measures recommended by CDC to prevent the spread of coronaviruses through droplets [12]. People at highest risk to covid-19 are healthcare professionals who are often involved in the treatment of infected patients. Despite this known fact by health workers, about 30\% of CRAs in this study do not always practice disinfection with the known methods worldwide. This could probably be that these measures are not treated with all the seriousness that it deserves by the workers in question which could be extrapolated to other health workers. It is important to protect healthcare workers to ensure continuity of care for patients. To prevent the spread of infection, delivery of N95 masks or availability of powered air-purifying respirators (PAPRs), protective suits and goggles for patients and hospital staff amid the COVID-19 pandemic should be a priority as well [10]. However, the findings of this study suggest that hospitals in Ghana are not fully resourced to always make available appropriate PPE and other protective equipment to CRAs to protect themselves during work as corroborated by World Health Organization. This, therefore, puts most CRAs at maximum risk of coronavirus infection when compared with other healthcare professionals who do not deal with directly the patients' airway most especially that surgeries have to still go on in the wake of the pandemic when patients are not tested before surgery in Ghana and most developing countries.

\section{Conclusion}

In conclusion, the findings of the study revealed that most CRAs have adequate knowledge about the causes and preventive measures necessary to prevent the spread of the virus. However, their attitude and practices at work visa vi preventive actions leave much to be desired. There is a need for regular in-service training of CRAs and other health workers on the right attitude and practices to prevent the spread of the virus among health workers. Policymakers should ensure regular supply of basic PPE at the various hospitals in the country.

\section{Limitation}

Our study is not without limitations. Testing for COVID-19 should be done for all Certified Registered Anaesthetists in Ghana to determine the total number of them that are infected with SARSCoV-2 during work.

\section{Declaration}

Ethics approval and consent to participate: The ethical committee of the Tamale Teaching Hospital approved the study protocol. Written informed consent was obtained from each respondent after providing them with adequate explanations regarding the aims of the study.

\section{Acknowledgement}

We thank the executives of the Ghana Association of Certified Registered Anaesthetists for permitting us to carry out this survey. We also thank all Certified Registered Anaesthetists practicing in Ghana for taking time out of their busy schedules to respond to our questionnaire.

\section{Conflict of Interest}

No conflict of interest.

\section{References}

1. CDC (2019) Novel Coronavirus, Wuhan, China.

2. WHO (2020) Coronavirus disease 2019 (COVID-19) Situation Report-48.

3. Ghana Health Service (2020) COVID-19 update website.

4. The New York Times (2020) Coronavirus Live Updates: W.H.O. Declares Pandemic as Number of Infected Countries Grows. The New York Times.

5. CDC (2019) Novel Coronavirus, Wuhan, China: Frequently Asked Questions and Answers

6. Li Q, Guan X, Wu P, Wang X, Lei Zhou, et al. (2020) Early Transmission Dynamics in Wuhan, China, of Novel Coronavirus-Infected Pneumonia. N Engl J Med 382(13): 1199-1207.

7. CDC (2020) Coronavirus Disease 2019 (COVID-19): Recommendations for Cloth Face Covers. Centres for Disease Control and Prevention.

8. CDC (2020) Coronavirus Disease 2019 (COVID-19): COVID-19 Situation Summary. CDC.

9. van Doremalen N, Bushmaker T, Morris DH, Holbrook MG, Gamble A, et al. (2020) Aerosol and Surface Stability of SARS-CoV-2 as Compared with SARS-CoV-1. N Engl J Med 382(16): 1564-1567. 
10. American Society of Anaesthesiology (2020) Anaesthesia Professionals at High Risk for Exposure to COVID-19 Should Wear Most-Protective Masks: ASA, APSF, AAAA \& AANA Issue Updated Statement.

11. Smith SM (2013) Determining sample size: How to ensure you get the correct sample size Blog post.
12. WHO (2020) Transmission of SARS-CoV-2: implications for infection prevention precautions? Scientific Brief.

13. Zuraw J (2020) Lost on frontline contributors. KHN.

14. Reuters (2020) Ghana Health Workers Warn of Potential COVID-19 Calamity. The New York. 